\title{
Bazı soya (Glycine max) çeşit ve hatlarının yağ içeriği ile yağ asitleri bileşimlerinin araştırılması*
}

\author{
Muharrem GÖLÜKCÜ ${ }^{\circledR}$ 1, Haluk TOKGÖZ $\left({ }^{1}\right.$, Mehmet KOCATÜRK $(\mathbb{1} 1$
}

${ }^{1}$ Batı Akdeniz Tarımsal Araştırma Enstitüsü Müdürlüğü, 07100 Antalya

Çalışma kısa özet şeklinde YABİTED II. Bitkisel Yağ Kongresi’nde poster olarak sunulmuştur.

Alınış tarihi: 12 Mart 2019, Kabul tarihi: 1 Ekim 2019

Sorumlu yazar: Muharrem GÖLÜKCÜ, e-posta: muharrem98@yahoo.com

Öz

Soya dünyada tarımı en fazla yaplan yağlı tohumlardan birisidir. Bu çalışmada Batı Akdeniz Tarımsal Araştırma Enstitüsü tarafından tescil ettirilen üç çeşit soya (BATEM-Erensoy, Umut-2002, Ataem-7) ile ıslah çalışmaları neticesinde geliştirilen ve çeşit adayı olarak belirlenen ileri kademedeki (F8F9) 11 adet soya hattının (BATEM-201, BATEM-202, BATEM-204, BATEM-208, BATEM-214, BATEM-215, BATEM-301, BATEM-306, BATEM-308, BATEM-322, BATEM-323) yağ içeriği ile yă asitleri bileșimini ortaya koymak amacıyla gerçekleştirilmiştir. Örneklerin yağ içeriği soxhelet yağ ekstraksiyon cihazı ile, yağ asitleri bileșimi de GC-MS/FID cihazı ile belirlenmiștir. Araștırma kapsamına incelenen çeșit ve hatların yağ içeriği \%19.91 (BATEM-204) ile \%21.76 (BATEM-322) arasında değişmektedir. Örneklerin tamamında baskın yă asidi linoleik asit (\%49.99-55.28) olup bu yağ asidini sırasiyla oleik (\%22.68-27.92), palmitik (\%11.28-11.99), linolenik (\%5.38-6.61), stearik asit (\%3.62-4.46) ve 11eikosenoik asit (\%0.11 ile \%0.24) takip etmiștir. Araștırma bulguları mevcut çeșit ve hatlarda yağ ve yağ asitleri bileșimi bakımından geniş bir varyasyon olduğunu göstermektedir.

Anahtar kelimeler: Soya, Glycine max., Çeşit, Hat, Yağ, Yağ asidi bileșimi
Oil content and fatty acid composition of some soybean (Glycine max.) cultivars and accessions

\begin{abstract}
Soybean is among the major oilseeds in the world. The aim of this study was to determine the oil content and fatty acid composition of three soybean cultivars (BATEM-Erensoy, Umut-2002, Ataem-7) and eleven soybean accessions (BATEM-201, BATEM-202, BATEM-204, BATEM-208, BATEM-214, BATEM-215, BATEM-301, BATEM-306, BATEM-308, BATEM-322, BATEM-323) developed by Batı Akdeniz Agricultural Research Institute. Oil contents of these samples determined by using soxhlet extractor and fatty acid composition with GC-MS/FID equipment. Oil content varied from 19.91\% (BATEM204) to $21.76 \%$ (BATEM-322) for these samples. The dominant fatty acid for all samples was linoleic acid (49.99- 55.28\%), and followed by oleic (22.68$27.92 \%)$, palmitic $(11.28-11.99 \%)$, linolenic (5.38$6.61 \%)$, stearic (3.62-4.46\%) and 11-eicosenoic acid (0.11- 0.24\%). Results showed that there was large variation in oil content and fatty acid composition for these soybean cultivars and accessions.
\end{abstract}

Key words: Soybean, Glycine max., Cultivar, Accession, Oil, Fatty acid composition 


\section{Giriş}

Soya (Glycine max.), baklagiller (Fabaceae) familyasında yer alan, anavatanı Uzakdoğu ülkeleri olan tek yıllık bitkidir. Soya dünyada üretimi en fazla yapılan yağlı tohumlardan birisidir (Lopes da Silva et al., 2017). 2017 yılı dünya soya üretimi 352643548 ton olarak gerçekleşmiştir. 2017 yılı verilerine göre dünya soya üretiminde 119518490 ton üretimi ile ABD ilk sırada yer almakta, bu ülkeyi sırasıyla Brezilya (114 599168 ton), Arjantin (54 971626 ton) ve Çin (13 152688 ton) takip etmektedir. Türkiye'de 2017 yılında soya üretim miktarı 140000 ton olarak gerçekleşmiştir (FAO, 2018). Soya, ülkemize ağırlıklı olarak Çukurova Bölgesinde üretilmektedir (Onurlubaş ve Kızllaslan, 2007).

Soya bașta bitkisel yağ olmak üzere, hayvan yemi, soya unu, soya sütü, soya sosu, lesitin gibi çok farklı ürünlere işlenmektedir (Liu, 1997). En yaygın kullanıldı̆̆ gelmektedir. Dünya bitkisel yağ ihtiyacını karşılamada palm yağından sonra en fazla kullanılan yağ soya yağıdır. Dünyada yemeklik bitkisel yağların yaklaşık 1/3'ü soyadan elde edilmektedir (Tayyar ve Gül, 2007). Dünyada 2014 yllında 45704551 ton soya yağı üretimi gerçekleşmiştir (FAO, 2019). Soyanın ortalama $\% 20$ yağ içeriğine sahip olduğu dikkate alındığında yaklaşık 228 milyon ton soyanın yağa işlendiği görülmektedir. Ülkemiz soya ve soya yağı ihtiyacının önemli bir kısmını ithalat yoluyla karşılamaktadır. Türkiye'nin 2017 yılında soya ve soya yağı için ithalata ödediği rakamlar sırasıyla 3 $445 \quad 369 \quad 170 \quad$ TL ve $344 \quad 936$ TL olarak gerçekleşmiştir (TUIK, 2018). Bu veriler ülkemiz için soya üretiminin ne kadar önemli olduğunu açıça göstermektedir. Türkiye'de farklı bölgelerde soya yetiştiriciliği konusunda bazı araştırmalar yapılmış ve yapılmaya devam etmektedir. Yapılan çalışmalarla ülkemizde soya üretiminin, üretim verileri ve bazı temel kalite kriterleri açısından mümkün olduğu gösterilmiştir (Yılmaz, 1999; Karasu ve ark., 2002; Sarımehmetoğlu, 2006; Tayyar ve Gül, 2007; Deliboran, 2009; Kınacl, 2011; Öztürk, 2011; Ay, 2012; Acar, 2014). Soya özellikle protein ve yağ içeriği ile öne çıkan bir gıda hammaddesidir. Soyanın \%18.0-22.0 yağ ve \%38.0-43.0 protein içerdiği bildirilmektedir (Yoshida et al., 2003). Dünyada, soyanın genel bileșimi yanında diğer bitkisel yağlarda olduğu gibi soya yağının kalitesi hakkında belirleyici olan yağ asitleri bileşimi üzerine de bazı çalıșmalar yapılmıștır. Soya ıslahında son yıllarda protein içeriğinin yanında yağ içeriği ve yağ asitleri bileşimi önem kazanmıştır (Clemente and Cahoon, 2009). Yapılan çalışmalarda soya yağının yağ asitleri bileşiminde doymamış yağ asitlerinden linoleik, oleik ve linolenik asitlerin oldukça önemli yer tuttuğu tespit edilmiştir. Beslenme açısından esansiyel yağ asitleri olan linoleik ve linolenik asitlerin yağ ve yağlı ürünlerde yüksek olması istenebilirken (Wang, 2011) bu ya ğ asitlerinin otooksidasyona duyarlı olması stabilite anlamında bir dezavantaj olabilmektedir. Tekli doymamış bir yağ asidi olan oleik asit ise beslenme ve yağın stabilitesi açısından da istenen bir yağ asididir (Warner and Gupta, 2005). Soya yağının yağ asitleri bileşiminin başta çeşit olmak üzere, yetiştirilme bölgesi gibi birçok faktörden etkilenebildiği ortaya konulmuştur (Galao et al., 2014). Soya yağının yağ asitleri bileşiminde \%8-17 palmitik asit, \%3-30 stearik asit, \%25-60 oleik asit, \%25-60 linoleik asit ve \%2-15 linolenik asidin yer aldığı bildirilmektedir (Liu, 1997). Özellikle bitkisel yağ ve protein ihtiyacını karşılamada oldukça önemli bir kaynak olan soya çeşit ıslahı konusunda ülkemizde önemli çalışmalar yapılmaktadır. Bu doğrultuda geliştirilen çeşitlerin ve çeşit olma yolunda olan soya hatlarının temel agronomik özelliklerinin yanında yağ içeriği ve yağın kalitesini gösteren parametrelerden en önemlisi olan yă̆ asitleri bileşimi gibi kalite özelliklerinin ortaya konulmasına ihtiyaç vardır.

$\mathrm{Bu}$ çalışmanın amacı farklı alanlarda kullanıma uygun Batı Akdeniz Tarımsal Araştırma Enstitüsü bünyesinde geliştirilen bazı soya çeşitleri ile ileri kademeye getirilmiş soya hatlarının yağ içeriği ve yağ asitleri bileşimini ortaya koymaktır.

\section{Materyal ve yöntem}

Çalışmada materyal olarak; Batı Akdeniz Tarımsal Araştırma Enstitüsü tarafından geliştirilen ve 2014 yılında ana ürün ürün koşullarında yetiştirilen, BATEM-Erensoy, Umut-2002 ve Ataem-7 tescilli çeşitleri ile ileri kademedeki (F8-F9) BATEM-201, BATEM-202, BATEM-204, BATEM-208, BATEM-214, BATEM-215, BATEM-301, BATEM-306, BATEM-308, BATEM-322 ve BATEM-323 soya hatları kullanılmıştır. Çeşit ve hatlara ait bazı özellikler Çizelge 1'de yer almaktadır. Araştırmanın yürütüldüğü lokasyonun 2014 yılı bazı iklim verileri Çizelge 2'de verilmiştir. Toprak yapısı tınlı olup ortlama \%29 kum, \%21 kil ve \%50 silt içermektedir. Toprak pH'sı ise ortalama 7,65'tir.

$\mathrm{Bu}$ amaçla öncelikle çeşit ve hatlardan elde edilen iç soya daneleri laboratuvar tipi öğütücüde (Retsch Grindomix GM 200) öğütme işlemine tabi 
tutulmuştur. Öğ̈̈tme işlemine tabi tutulan örnekler yağ tayini işleminden önce $70^{\circ} \mathrm{C}^{\prime}$ de kurutma fırınında kurutulmuştur. Öğ̈̈ülüp kurutulan örneklerin yağ miktarı tayini, soxhelet otomatik yağ ekstraksiyon cihazında (Gerhardt, Soxtherm 2000) petrol eteri kullanılarak gerçekleştirilmiştir (AOAC, 2005). Bu amaçla $5 \mathrm{ml}$ örnek, $140 \mathrm{ml}$ petrol eteri kullanılmıștır. Ekstraksiyon sıcaklığı $150^{\circ} \mathrm{C}$, kaynama süresi 30 dakika, ekstraksiyon süresi 80 dakika olarak ayarlanmıştır. Örneklere ait toplam yağ içerikleri kuru madde üzerinden verilmiştir. Örneklerden ekstraksiyon yoluyla elde edilen yağların yağ asitleri bileşimi gaz kromatografisi-kütle spektrometresi/alev iyonlaştırmalı dedektör cihazı (GC-MS/FID, Agilent) ile belirlenmiştir. Bu amaçla öncelikle yağlardan yağ asitleri metil esterleri “Türk Gıda Kodeksi Zeytinyağı ve Pirina Yağı Analiz Metotları" tebliğine göre hazırlanmıştır (Anonymous, 2014). Daha sonra yağ asidi bileşim analizi için hazırlanan örnekler gaz kromatografisi cihazına enjekte edilmiştir. Analizler 40:1 oranında split modda gerçekleştirilmiş olup enjeksiyon miktarı $1 \mu$ l'dir. Analizlerde taşıyıcı gaz olarak $0.8 \mathrm{ml} /$ dakika akış hızında helyum gazı kullanılmıştır. Bileșenlerin ayrımı kapiler kolon (HP Innowax Capillary; $60.0 \mathrm{mx} 0.25 \mathrm{~mm} \times 0.25 \mu \mathrm{m}$ ) ile gerçekleştirilmiştir. Analizlerde uygulanan kolon sicaklık programı, $150^{\circ} \mathrm{C}$ 'den $230^{\circ} \mathrm{C}$ 'ye $2^{\circ}$ /dakika ile yükselme ve $230^{\circ} \mathrm{C}^{\prime}$ de 10 dakika tutma (toplam analiz süresi 50 dakika) şeklinde olmuştur. . Elde edilen piklerin tanımlamaları kullanılan yağ asidi metil esterleri standartları ve MS dedektörü yardımıyla yapılmıştır. Bileşen tanımlamasında MS dedektörünün WILEY7N, NIST05, OIL ADAMS kütüphane verilerinden faydalanılmıştır. Yağ asitlerinin oranlarının belirlenmesinde ise FID dedektöründen elde edilen veriler kullanılmıştır.

Çalışma tesadüf parselleri deneme düzeninde iki tekerrürlü olarak gerçekleştirilmiştir (Düzgüneş ve ark., 1987). Araştırma verileri SAS paket programı kullanılarak Duncan Çoklu Karşılaştırma Testi işlemine tabi tutulmuştur. Sonuçlar ortalama sstandart hata şeklinde verilmiştir.

Çizelge 1. Araştırmada kullanılan çeşit ve hatların bazı özellikleri

\begin{tabular}{ccccc}
\hline Örnek & $\begin{array}{c}\text { Vejetas- } \\
\text { yon süre } \\
\text { (gün) }\end{array}$ & $\begin{array}{c}\text { Bitki } \\
\text { boyu } \\
\text { (cm) }\end{array}$ & $\begin{array}{c}\text { Bakla } \\
\text { sayıs } \\
\text { (adet/bitki) }\end{array}$ & $\begin{array}{c}\text { Verim } \\
\text { (kg/da) }\end{array}$ \\
\hline BATEM-201 & 124 & 129 & 73 & 370 \\
BATEM-202 & 124 & 130 & 68 & 372 \\
BATEM-204 & 127 & 137 & 76 & 360 \\
BATEM-208 & 124 & 141 & 69 & 384 \\
BATEM-214 & 124 & 110 & 75 & 394 \\
BATEM-215 & 124 & 115 & 77 & 383 \\
BATEM-301 & 125 & 140 & 62 & 298 \\
BATEM-306 & 124 & 139 & 65 & 315 \\
BATEM-308 & 125 & 140 & 85 & 427 \\
BATEM-322 & 128 & 145 & 54 & 301 \\
BATEM-323 & 125 & 125 & 64 & 283 \\
Ataem-7 & 125 & 129 & 66 & 349 \\
Batem-Erensoy & 127 & 138 & 72 & 405 \\
Umut-2002 & 124 & 130 & 70 & 351 \\
\hline
\end{tabular}

Çizelge 2. Araştırmanın yürütüldüğü lokasyonun 2014 yılı iklim verileri.

\begin{tabular}{ccccccccccccc}
\hline İklim özellikleri & Ocak & Şubat & Mart & Nisan & Mayıs & Haziran & Temmuz & Ağustos & Eylül & Ekim & Kasım & Aralık \\
\hline Yağış (mm) & 111.0 & 47.4 & 76.4 & 41.0 & 27.2 & 0.0 & 0.0 & 5.4 & 20.0 & 120.2 & 39.4 & 125.8 \\
Oransal nem (\%) & 83.3 & 76.3 & 70.4 & 75.4 & 73.4 & 57.9 & 68.9 & 71.6 & 67.3 & 66.8 & 68.8 & 81.0 \\
Ort. sıcaklık $\left({ }^{\circ} \mathrm{C}\right)$ & 11.2 & 11.4 & 13.5 & 16.6 & 20.2 & 25.3 & 27.5 & 28.4 & 25.0 & 20.1 & 14.0 & 13.3 \\
Mak, sıcaklık $\left({ }^{\circ} \mathrm{C}\right)$ & 17.4 & 18.5 & 19.9 & 22.7 & 25.9 & 32.1 & 33.1 & 34.8 & 31.1 & 26.9 & 21.3 & 18.4 \\
Min, sıcaklık $\left({ }^{\circ} \mathrm{C}\right)$ & 6.4 & 5.3 & 7.4 & 10.2 & 14.3 & 18.0 & 21.3 & 22.3 & 19.4 & 14.1 & 9.4 & 9.8 \\
\hline
\end{tabular}

\section{Bulgular ve tartışma}

Çalışmada kullanılan çeşit ve hatlara ait örneklerin toplam yağ içeriği ile doymuş yağ asitleri bileşimine ait Duncan Çoklu Karşılaştırma Testi sonuçları Çizelge 3'de, doymamış yağ asitleri bileşimine ait sonuçlar da Çizelge 4'de verilmiştir.
Araştırma kapsamında incelenen çeşit ve hatların toplam yağ içeriği çeşit ve hatlara göre istatistiksel olarak önemli farklıllklar göstermiștir. Örneklerin yağ içeriği \%19.91 (BATEM-204) ile \%21.72 (BATEM-322) arasında değişmiştir (Çizelge 3). Analiz edilen çeşit ve hatlar için ortalama toplam yağ içeriği \%20.81 olarak hesaplanmıştır. 
Çizelge 3. Bazı soya çeşit ve hatlarının yağ içerikleri ile doymuş yağ asitleri bileşimi (\%, ortalamaıstandart hata).

\begin{tabular}{ccccc}
\hline Örnek & Toplam yă & Palmitik asit & Stearik asit & Araşidik asit \\
\hline BATEM-201 & $21.33^{\mathrm{ab} \pm 0.45}$ & $11.60^{\mathrm{a}} \pm 0.21$ & $3.99^{\mathrm{bc} \pm 0.12}$ & $0.34^{\mathrm{a}} \pm 0.07$ \\
BATEM-202 & $20.19^{\mathrm{b}} \pm 0.40$ & $11.74^{\mathrm{a}} \pm 0.21$ & $4.09^{\mathrm{ab} \pm 0.14}$ & $0.35^{\mathrm{a} \pm 0.04}$ \\
BATEM-204 & $19.91^{\mathrm{c}} \pm 0.32$ & $11.34^{\mathrm{a}} \pm 0.28$ & $4.08^{\mathrm{abc} \pm 0.07}$ & $0.33^{\mathrm{a} \pm 0.07}$ \\
BATEM-208 & $20.85^{\mathrm{abc} \pm 0.45}$ & $11.28^{\mathrm{a}} \pm 0.19$ & $3.72^{\mathrm{bc} \pm 0.23}$ & $0.31^{\mathrm{a} \pm 0.05}$ \\
BATEM-214 & $20.84^{\mathrm{abc} \pm 0.22}$ & $11.63^{\mathrm{a}} \pm 0.34$ & $4.04^{\mathrm{abc} \pm 0.16}$ & $0.34^{\mathrm{a} \pm 0.05}$ \\
BATEM-215 & $20.41^{\mathrm{bc} \pm 0.33}$ & $11.83^{\mathrm{a} \pm 0.22}$ & $4.08^{\mathrm{abc} \pm 0.09}$ & $0.34^{\mathrm{a} \pm 0.03}$ \\
BATEM-301 & $20.26^{\mathrm{bc} \pm 0.21}$ & $11.63^{\mathrm{a} \pm 0.11}$ & $4.01^{\mathrm{abc} \pm 0.18}$ & $0.34^{\mathrm{a} \pm 0.02}$ \\
BATEM-306 & $20.98^{\mathrm{abc} \pm 0.35}$ & $11.56^{\mathrm{a}} \pm 0.15$ & $4.11^{\mathrm{a}} \pm 0.12$ & $0.33^{\mathrm{a} \pm 0.06}$ \\
BATEM-308 & $20.25^{\mathrm{bc} \pm 0.27}$ & $11.64^{\mathrm{a}} \pm 0.08$ & $3.88^{\mathrm{bc} \pm 0.16}$ & $0.32^{\mathrm{a} \pm 0.05}$ \\
BATEM-322 & $21.72^{\mathrm{a} \pm 0.29}$ & $11.61^{\mathrm{a}} \pm 0.36$ & $3.78^{\mathrm{bc} \pm 0.14}$ & $0.36^{\mathrm{a} \pm 0.05}$ \\
BATEM-323 & $21.29^{\mathrm{ab} \pm 0.36}$ & $11.59^{\mathrm{a}} \pm 0.26$ & $3.62^{\mathrm{c} \pm 0.06}$ & $0.37^{\mathrm{a} \pm 0.02}$ \\
Ataem-7 & $21.12^{\mathrm{abc} \pm 0.46}$ & $11.44^{\mathrm{a}} \pm 0.25$ & $3.99^{\mathrm{bc} \pm 0.16}$ & $0.32^{\mathrm{a} \pm 0.03}$ \\
Batem-Erensoy & $20.97^{\mathrm{abc} \pm 0.35}$ & $11.88^{\mathrm{a}} \pm 0.07$ & $4.45^{\mathrm{a} \pm 0.05}$ & $0.34^{\mathrm{a} \pm 0.02}$ \\
Umut-2002 & $21.18^{\mathrm{ab} \pm 0.47}$ & $11.97^{\mathrm{a}} \pm 0.06$ & $3.93^{\mathrm{bc} \pm 0.06}$ & $0.32^{\mathrm{a} \pm 0.03}$ \\
\hline
\end{tabular}

Çizelge 4. Bazı soya çeşit ve hatlarının doymamış yağ asitleri bileşimi (\%, ortalamaさstandart hata).

\begin{tabular}{|c|c|c|c|c|}
\hline Örnek & Oleik asit & Linoleik asit & Linolenik asit & 11-eikosenoik asi \\
\hline BATEM-201 & $24.90^{\mathrm{ef}} \pm 0.22$ & $52.99^{\mathrm{bcde}} \pm 0.48$ & $5.94^{\text {cde }} \pm 0.08$ & $0.24^{\mathrm{a}} \pm 0.01$ \\
\hline BATEM-202 & $27.48^{a} \pm 0.27$ & $50.57^{\mathrm{gh}} \pm 0.30$ & $5.54^{\mathrm{fg}} \pm 0.09$ & $0.24^{a} \pm 0.03$ \\
\hline BATEM-204 & $22.68^{\mathrm{h}} \pm 0.27$ & $55.28^{\mathrm{a}} \pm 0.32$ & $6.09^{c} \pm 0.09$ & $0.21^{\mathrm{a} \pm 0.03}$ \\
\hline BATEM-208 & $26.68^{\mathrm{b}} \pm 0.09$ & $51.94^{\mathrm{def}_{ \pm}} \pm 0.17$ & $5.86^{\mathrm{de}} \pm 0.06$ & $0.22^{\mathrm{a} \pm 0.03}$ \\
\hline BATEM-214 & $26.63^{\mathrm{b}} \pm 0.21$ & $51.75^{\mathrm{efg}} \pm 0.20$ & $5.38 \mathrm{~g} \pm 0.05$ & $0.23^{a} \pm 0.01$ \\
\hline BATEM-215 & $23.76^{g} \pm 0.22$ & $54.03^{\mathrm{b}} \pm 0.52$ & $5.75^{\mathrm{def}} \pm 0.01$ & $0.22^{\mathrm{a}} \pm 0.03$ \\
\hline BATEM-301 & $27.92^{\mathrm{a}} \pm 0.13$ & $49.99^{\mathrm{h}} \pm 0.61$ & $5.88^{\mathrm{cde}} \pm 0.03$ & $0.24^{a} \pm 0.02$ \\
\hline BATEM-306 & $24.39^{\mathrm{fg} \pm 0.43}$ & $53.09^{\mathrm{bcd}} \pm 0.37$ & $6.31^{\mathrm{b} \pm 0.08}$ & $0.22^{a} \pm 0.03$ \\
\hline BATEM-308 & $25.45^{\mathrm{de}} \pm 0.16$ & $52.72^{\text {cde }} \pm 0.23$ & $5.77^{\mathrm{de}} \pm 0.07$ & $0.23^{a} \pm 0.03$ \\
\hline BATEM-322 & $26.13^{\mathrm{cbd}} \pm 0.25$ & $52.19^{\text {cdef }} \pm 0.43$ & $5.72^{\mathrm{ef}} \pm 0.06$ & $0.22^{\mathrm{a}} \pm 0.01$ \\
\hline BATEM-323 & $24.23^{\mathrm{fg} \pm 0.44}$ & $53.37 \mathrm{bc} \pm 0.30$ & $6.61^{a} \pm 0.09$ & $0.23^{a} \pm 0.02$ \\
\hline Ataem-7 & $23.96^{g} \pm 0.26$ & $54.21^{\mathrm{ab}} \pm 0.24$ & $5.97^{\mathrm{cd}} \pm 0.08$ & $0.11^{\mathrm{b}} \pm 0.03$ \\
\hline BATEM-Erensoy & $25.68^{\mathrm{cde}} \pm 0.14$ & $52.06^{\text {cdef }} \pm 0.42$ & $5.39 \mathrm{~g} \pm 0.04$ & $0.19^{\mathrm{a}} \pm 0.02$ \\
\hline Umut-2002 & $26.41^{\mathrm{cb} \pm 0.26}$ & $51.31^{\mathrm{fg} \pm 0.45}$ & $5.96^{\mathrm{cd}} \pm 0.06$ & $0.11^{\mathrm{b}} \pm 0.02$ \\
\hline
\end{tabular}

Her sütundaki farklı harfler ortalamalar arasında $\mathrm{P}<0.05$ seviyesinde fark olduğunu göstermektedir.

Tescilli standart çeșitlerin yağ içeriği en yüksek \%21.18 ile Umut-2002 çeșidinde tespit edilmiș iken ıslah çalışmaları sonucu geliștirilen hatların bir kısmında bu değerin üzerine ulașılmıștır. Elde edilen veriler yağ verimi açısından BATEM-322 hattının mevcut çeşitlerden daha iyi olduğunu göstermektedir. Bu veriler ıslah çalışmaları ile bu tip kimyasal bileșime yönelik özelliklerde kısmi olarak gelișmeler sağlanabileceğini göstermektedir. Nitekim farklı soya çeşitleri üzerine yapılan çalışmalar da bunu doğrular niteliktedir. Farklı soya çeşitlerinin ana ve ikinci ürün yetiştiriciliğinin ürün kalitesi üzerine olan etkisinin belirlenmesine yönelik çalışma sonucunda soya bileşiminde uygulanan faktörlere göre önemli farklıllklar olduğu görülmüştür. Araştırma kapsamında incelenen örneklerin yă̆ içeriğinin $\% 16.59$ ile \%20.26 aralığında dağılım gösterdiği belirtilmiştir (Acar, 2014). Esteves et al. (2010) UFV-116 ve OCEPAR-19 soya çeşitlerinin yağ içeriklerini sırasıyla \%20.83 ve $\% 22.57$ olarak tespit etmişlerdir. Yoshida et al. (2003) ise soyanın yağ içeriğ̌inin \%18-22 aralı̆̆ında 
değişim gösterdiğini belirtmişlerdir. Soyanın toplam yağ içeriği üzerinde hasat zamanın da oldukça önemli etkiye sahip olduğu yapılan bir çalışma ile ortaya konulmuştur. Yapılan çalışmada, farklı dönemlerde hasat edilen soyanın toplam yağ oranının \%13.1 ile \%19 arasında değiștiği ortaya konulmuştur (Öz ve Karasu, 2007).

Bulgularımız Esteves vd. (2010) ile Yoshida vd. (2003) ile benzerlikler gösterirken, Acar (2014) ile Öz ve Karasu (2007)'nun bulgularından bazı farklılıklar göstermiștir. Bu farklılı̆̆ın bașta materyal farklılı̆̆ı olmak üzere yetiştirme koşullarındaki farklıklardan ileri gelebileceği düșünülmektedir. Yılmaz (1999) tarafından yapılan çalışmada da çeşit, yetiştirilme yılı ve bitki sıra arası gibi faktörlere göre soya yağ içeriğinin önemli oranlarda değiștiği ortaya konulmuştur. Sarımehmetoğlu (2006) tarafindan yapılan çalışmada ise soyanın yetiştirilme lokasyonuna göre yağ içeriğinde önemli farklılıklar olabileceği tespit edilmiştir.

Çalışma kapsamında analizi yapılan çeşit ve hatlardan elde edilen yağların yă̆ asitleri bileșiminde üç adet doymuș (palmitik, stearik, araşidik) ve dört adet de (oleik, linolenik, linolenik, 11-eikosenoik) doymamış olmak üzere toplam yedi farklı yağ asidinin yer aldığı belirlenmiștir. Doymuş yağ asitleri olarak soya yağlarının bileşiminde yer alan palmitik stearik ve araşidik asit oranları sirasiyla \%11.28-11.97, \%3.62-4.45, \%0.31-0.37 aralıklarında dağılım göstermiştir. Örneklerin, oransal olarak en yüksek doymuş yağ asidi olan palmitik ve en düşük düzeydeki doymuş yağ asidi olan araşidik asit oranları arasındaki rakamsal farklılıklar istatistiksel olarak önemsiz düzeyde iken $(P>0.05)$, stearik asit oranları arasındaki farklılıklar önemli düzeyde olmuştur $(\mathrm{P}<0.05) \quad$ (Çizelge 3$)$. Çalışma kapsamında yer alan çeşit ve hatlara ait tohumlardan elde edilen yağların toplam doymuş yağ asitleri oranı da \%15.31 ile \%16.67 aralığında değișim göstermiștir. Beslenme açısından doymuş yağ asitleri oranının daha düşük olması istenmektedir. BATEM-208 ve BATEM-323 hatları mevcut çeşitlere göre daha düşük oranda toplam doymuş yağ asidi içermektedir. Soya yağının yağ asitleri bileșimi üzerine bazı çalıșmalar yapılmıștır. Galao et al. (2014) tarafından yapılan çalışmada soya yağının yă̆ asitleri bileșiminin yetiștirilme bölgesi ve çeşide göre farklılıklar gösterdiği ortaya konulmuştur. Araştırıcılar soya yağının bu faktörlere göre palmitik, stearik ve araşidik asit oranlarının sirasiyla \%10.06-13.48, \%3.19-4.62, \%0.00-0.23 aralığında değiştiğini belirlemişlerdir. Yaplan bir diğer çalıșmada ise soya yağının palmitik ve stearik asit içeriklerinin sırasıyla \%10.63-11.43, \%3.76-4.61 aralığında olduğu tespit edilmiştir (Esteves et al., 2010). Öktem ve ark. (1997) tarafından piyasadan temin edilen soya yağlarının yağ asitleri bileşiminin belirlenmesine yönelik çalışmada da soya yağı için palmitik ve stearik asit oranları sırasıyla \%11.24 ve \%3.56 olarak saptanmıştır. Schulte et al. (2013) de yaptıkları çalışmada soya yağının bileşiminde palmitik ve stearik asit olmak üzere iki adet doymuş yağ asidinin bulunduğunu ve oranlarının sırasıyla $\% 11$ ve \%4 olduğunu belirlemişlerdir. Yapılan çalışmalar ile bulgularımız arasında genel bir değerlendirme yapıldığında benzerlikler olduğu görülecektir. Bulgular arasındaki bazı küçük farklılıkların ise kullanılan çeşit, yetiştirilme bölgesi gibi farklılıklardan kaynaklanabileceği düşünülmektedir.

Diğer bitkisel yağların çoğunda olduğu gibi soya yağı da özellikle doymamış yağ asitleri açısından oransal olarak oldukça zengindir. Çalışmada incelenen çeşit ve hatların doymamış yağ asitleri bileşimleri arasında istatistiksel olarak önemli farklılıklar olduğu görülmüştür (Çizelge 4). Örneklerde doymamış yağ asitlerinden birisi olan ve yapısından iki adet doymamış bağ içeren linoleik asit baskın yağ asididir. Bu yağ asidi beslenme açısından esansiyel bir yağ asidi olarak bilinmektedir. Linoleik asidin örneklerdeki oranları araştırma kapsamında analiz edilen çeşit ve hatlarda \%49.99 (BATEM-301) ile \%55.28 (BATEM-204) aralığında dağılım göstermiştir (Çizelge 4). Bu veriler linoleik asit açısından soya yağının ne kadar zengin olduğunu göstermektedir. Esansiyel bir yağ asidi olan linoleik asidin doğrudan tüketilen gıdalarda yüksek olması avantaj olabilmektedir. $\mathrm{Bu}$ anlamda BATEM-204 hattı ön plana çıkmaktadır. Ancak işlenmiş ve depolanması gereken ürünlerde ise bu yağ asidinin düşük olması önem kazanabilmektedir. Bu bakımdan değerlendirme yapıldığında da BATEM-301 hattı ön plana çlkabilmektedir. Ancak bu verilerin antioksidan içeriği gibi diğer faktörlerle birlikte değerlendirilmesi yerinde olacaktır. Soya yağının bileşiminde oldukça önemli yer tutan bir diğer doymamış yağ asidi oleik asit olup, bu yağ asidi araştırma örneklerinden ekstrakte edilen soya yağlarında linoleik asidin yaklaşık yarısı oranında bulunmaktadır. Örneklerdeki oleik asit miktarı \%22.68 (BATEM-204) ile \%27.92 (BATEM-202) arasında dağılım göstermiştir (Çizelge 4). Doymamış 
yağ asitlerinden birisi olan oleik asit otooksidasyon açısından linoleik ve linolenik asitlere oranlara daha stabil bir yağ asididir. Bu durum da işlenmiş ürünlerde bu yağ asidinin yüksek olması avantaj olarak değerlendirilebilir. Bu veriler üzerinden değerlendirme yapıldığında da BATEM-204 hattının daha üstün özellikte olduğu söylenebilir. Genel bir değerlendirme yapıldığında da linoleik asit ile oleik asit arasında ters orantı olduğu görülecektir. Linoleik asit içeriği yüksek örneklerin oleik asit içeriği daha düşüktür. Nitekim soya yağı için oleik ve linoleik asit arasında böyle bir ilişkinin olduğu belirtilmektedir (Liu, 1997). Elde edilen veriler göz önüne alındığında ıslah çalışmaları ile bu anlamda da varyasyon oluşturmanın mümkün olduğu görülecektir. Linoleik ve oleik aside göre soya yağında daha düşük oranda bulunan ve çeşit ve hatların tamamında tespit edilen diğer iki doymamış yağ asidi de linolenik ve 11-eikosenoik asit olarak belirlenmiştir. Yapısında üç adet doymamış bağ içeren linolenik asit miktarı \%5.38 (BATEM-214) ile \%6.61 (BATEM-323) aralığında varyasyon göstermiştir. Çeşit ve hatlara ait tohumlardan elde edilen yağlarda tespiti yapılan doymuş ve doymamıș yağ asitlerine göre oransal olarak en düşük düzeyde olan 11-eikosenoik asit ise \%0.11 ile \%0.24 aralığında dağılım göstermiştir (Çizelge 4). Bu yă asidi için en düşük değerler tescilli çeşitlerde görülmüştür. Örneklerin doymamış yağ asitleri toplamına göre bir değerlendirme yapıldığında da soya yağı bileşimindeki doymamış yağ asitlerinin oranının \%83.33 (BATEM-Erensoy) ile \%84.69 (BATEM-208) arasında değiştiği görülecektir. Literatür değerleri incelendiğinde soya yağının doymamış yağ asitleri bileşiminde çeşit başta olmak üzere çeşitli faktörlere göre farklılıklar olduğu görülecektir. Öktem ve ark. (1997) tarafından yapılan çalışmada soya yağının yağ asidi bileşiminde oleik, linoleik ve linolenik doymamış yağ asitlerinin bulunduğu ve bunların sirasıyla \%25.02, \%54.44, \%5.71 olduğu tespit edilmiştir. Galao et al. (2014) ise soya yağının oleik, linoleik ve linolenik asit oranlarını sirasıyla \%13.46-20.63, \%53.32-59.34, \%7.38-11.89 olarak bildirmişlerdir. Farklı ekstraksiyon yöntemlerinin soya yağının kalitesi üzerine etkisinin belirlenmesi amacıyla yürütülen çalışmada da örneklerin oleik, linoleik ve linolenik asit içeriklerinin sırasıyla \%21.47-23.72, \%55.0756.65, \%5.68-5.77 aralığında dağılım gösterdiği tespit edilmiştir (Hoşgün, 2008). Grela and Günter (1995) tarafından yürütülen çalışmada da soya yağının yağ asidi bileșiminde $\% 26.9$ oleik asit, \%53.3 linoleik asit, \%6.4 linolenik asit bulunduğu ortaya konulmuştur. Yapılan bir diğer çalışmada da çeşitlere göre soya yağının yağ asitleri bileşiminde \%21.68-21.86 oleik asit, \%54.86-55.38 linoleik ve \%7.75-8.03 linolenik asidin yer aldığ bildirilmiștir (Estevest et al., 2010). Genel bir değerlendirme yapıldığında bulgularımızın literatür değerleri ile genel olarak uyum içinde olduğu görülecektir. Ancak araştırma bulgularımız ile Galao et al. (2014) tarafından ortaya konulan bulgular arasında bazı farklılıklar bulunmaktadır. Bunun da araştırmada kullanılan materyal farklılı̆̆ı bașta olmak üzere yetiştirilme şartları, uygulanan kültürel işlemler gibi farklılıklardan ileri gelebileceği düşünülmektedir.

\section{Sonuç}

Dünya yağ üretiminde oldukça önemli bir konuma sahip olan soya üretiminde ülkemiz istenilen paya sahip değildir. Türkiye'de soya ve soya yağı ihtiyacı ithalat yoluyla karşılanmakta olup bunun için önemli miktarlarda ödemeler yapılmaktadır. Oysaki ülkenin iklim ve toprak yapısı diğer birçok bitkide olduğu gibi soya üretimi yapılmasına uygundur. Nitekim yapılan çalışmalar da bunun mümkün olduğunu göstermektedir. Üretim çalışmaları soyanın temel kalite kriterleri açısından dünyada üretimi yapılanlarla benzerlikler arzettiğini göstermektedir. Çalışma kapsamında bazı tescilli soya çeşitlerinin ve ıslah çalışmaları sonucunda ileri kademelere ulaşmış soya hatlarının beslenme ve endüstriyel alanda da yağ üretimi açısından en önemli kalite kriterleri olan yağ içeriği ve yağ asitleri bileşimleri ortaya konulmuştur. Çalışma kapsamındaki materyallerin toplam yağ içeriği \%19.91-21.72 aralığındadır. Yağ asitleri bileşimi değerlendirildiğinde de doymamış yağ asidi olarak linoleik ve oleik asidin, doymuş yağ asidi olarak da palmitik asidin öne çlktığ görülmüştür. Doymamış yağ asitlerinin doymuş yağ asitlerine oranı (doymamış yağ asitleri/doymuş yağ asitleri) 5.00 ile 5.53 aralı̆̆ında değișmektedir. Yağ asitleri bileşimindeki farklılık nedeniyle kullanım alanını belirlemede önemli olan yağın fiziksel ve oksidatif stabilitesi gibi özellikleri de değişebilmektedir. Veriler melezleme çalışmaları ile esansiyel yağ asitleri açısından zengin tüketime uygun ve alternatif ürünlere işlenebilecek stabilitesi yüksek çeşitlerin geliştirilmesinin mümkün olduğunu göstermektedir. Sonuç olarak; yağ içeriği ve yağ asitleri bileşimi kalite kriterlerinde talepler doğrultusunda varyasyon yaratmanın mümkün olduğu görülmüştür. 


\section{Kaynaklar}

Acar, N., 2014. Değișik Kökenli Farklı Soya [Glycine max L.(Merrill)] Çeşitlerinin Kahramanmaras Koşullarında Ana Ürün ve II. Ürün Olarak Verim ve Kalite Özelliklerinin İncelenmesi. Kahramanmaraș Sütçü İmam Üniversitesi Fen Bilimleri Enstitüsü, Yüksek Lisans Tezi, Kahramanmaraș, $65 \mathrm{~s}$.

Anonim, 2014. Türk gıda kodeksi zeytinyağı ve pirina yağı analiz metotları tebliği. Tebliğ No: 2014/53. Resmi Gazete, Sayı: 29181.

AOAC, 2005. Official Methods of Analysis AOAC INTERNATIONAL. 18th Edition, Washington DC, the USA.

Ay, B., 2012. Türkiye'de Islah Edilmiș Yeni Soya (Glycine max. L. Merrill) Çeşitlerinin Orta Karadeniz Bölgesi Koşullarında Verim Ve Kalite Performanslarının Belirlenmesi. Ondokuz Mayıs Üniversitesi Fen Bilimleri Enstitüsü, Yüksek Lisans Tezi, Samsun, 68 S.

Clemente, T.E., Cahoon, E.B., 2009. Soybean oil: Genetic approaches for modification of functionality and total content. Plant Physiology, 151: 1030-1040.

Deliboran, A., 2009. Harran Ovası Koşullarında Farklı Sulama Miktarlarının ve Fosfor Magnezyum Dozlarının Soyada (Glycine max. L.) Verim ve Kalite Unsurları Üzerine Etkisi. Harran Üniversitesi Fen Bilimleri Enstitüsü, Doktora Tezi, Șanlıurfa, 343 s.

Düzgüneş, O., Kesici, T., Kavuncu, O., Gürbüz, F., 1987. Araștırma ve Deneme Metotları. Ankara Üniversitesi, Ziraat Fakültesi Yayınları No: 1021, Ankara, $381 \mathrm{~s}$.

Esteves, E.A., Martino, H.S.D., Oliveira, F.C.E., Bressan, J., Costa, N.M.B., 2010. Chemical composition of a soybean cultivar lacking lipoxygenases (LOX2 and LOX3). Food Chemistry, 122: 238-242.

FAO, 2018. Statistical database. (Web page: http://www.fao.org/faostat/en/\#data/QC), (Date accessed: 18 June, 2018).

Galao, O.F., Carrao-Panizzi, M.C., Mandarino, J.M.G., Junior, O.O.S., Maruyama, S.A., Figueiredo, L.C., Bonafe, E.G., Visentainer, J.V., 2014. Differences of fatty acid composition in Brazilian genetic and conventional soybeans (Glycine max (L.) Merrill) grown in different regions. Food Research International, 62: 589-594.

Grela, E.R., Günter, K.D., 1995. Fatty acid composition and tocopherol content of some legume seeds. Animal Feed Science and Technology, 52: 325-331.

Hoşgün, E.Z., 2008. Farklı Yöntemlerle Soya Yağı Ekstraksiyonu ve Karakterizasyonu. Anadolu
Üniversitesi Fen Bilimleri Enstitüsü, Yüksek Lisans Tezi, Eskișehir, $100 \mathrm{~s}$.

Karasu, A., Öz, M., Göksoy, A.T., 2002. Bazı soya fasulyesi [Glycine $\max$ (L.) Merill] çeşitlerinin Bursa koşullarına adaptasyonu konusunda bir çalışma. Uludağ Üniversitesi Ziraat Fakültesi Dergisi, 16 (2): 25-34.

Kınacı,, M., 2011. Çanakkale Koşullarında Soya Fasulyesi Çeşitlerinin Verim ve Bazı Kalite Unsurlarının Belirlenmesi. Selçuk Üniversitesi Fen Bilimleri Enstitüsü, Yüksek Lisans Tezi, Konya, 76 s.

Liu, K., 1997. Soybeans Chemistry, Technology, and Utilization. Chapman \& Hall, New York, USA, 532 pp.

Lopes da Silva, F., Borem, A., Sediyama, T., \& Ludke, W.H., 2017. Soybean Breeding. Springer, USA, 400 pp.

Onurlubaş, H.E., Kızılaslan, H., 2007. Türkiye'de Bitkisel Yağ Sanayindeki Gelișmeler ve Geleceğe Yönelik Beklentiler. Tarımsal Ekonomi Araştırma Enstitüsü Yayınları, Yayın No: 157, Ankara, 72 s.

Öktem, A.B., Yentür, G., Kıral, N., Orman, M., 1997. Ankara piyasasından sağlanan soya yağı ve ayçicek yağlarında yă̆ asitleri miktarları üzerinde araştırmalar. Ankara Üniversitesi Veteriner Fakültesi Dergisi, 44: 1-5.

Öz, M., Karasu, A., 2007. Farklı Gelişme dönemlerinde hasat edilen soya tohumlarına ait bazı özelliklerin incelenmesi. Uludağ Üniversitesi Ziraat Fakültesi Dergisi, 21 (1): 81-91.

Öztürk, F., 2011. Ön Bitki, Toprak İșleme ve Azot Kaynağının İkinci Ürün Soyada Verim, Kalite ve Nodül Olușumu Üzerine Etkileri. Dicle Üniversitesi Fen Bilimleri Enstitüsü, Yüksek Lisans Tezi, Diyarbakır, 135 s.

Sarımehmetoğlu, O., 2006. Çukurova Bölgesi Çiftçi Koșullarında Yetiștirilen Soya Ürününde Bazı Önemli Kalite Özelliklerinin Belirlenmesi. Cukurova Üniversitesi Fen Bilimleri Enstitüsü, Yüksek Lisans Tezi, Adana, 74 s.

Schulte, L.R., Ballard, T., Samarakoon, T., Yao, L., Vadlani, P., Staggenborge, S., Rezac, M., 2013. Increased growing temperature reduces content of polyunsaturated fatty acids in four oilseed crops. Indistrial Crops and Products, 51: 212-219.

Tayyar, Ş., Gül, M.K., 2007. Bazı soya fasulyesi (Glycine max (L.) Merr.) genotiplerinin ana ürün olarak Biga şartlarındaki performansları. Yüzüncü Yıl Üniversitesi Tarım Bilimleri Dergisi, 17 (2): 55-59

TUIK, 2018. Bitkisel Üretim İstatistikleri. (Web sayfası: http://www.tuik.gov.tr/), (Erişim Tarihi: 18.06.2018). 
Wang, T., 2011. "Soybean Oil, 59-105”. In: Vegetable Oils in Food Technology Composition, Properties and Uses, Second Edition (Eds. F.D. Gunstone), A John Wiley \& Sons Ltd., Publications, Oxford, UK, 353 pp.

Warner, K., Gupta, M., 2005. Potato chip quality and frying oil stability of high oleic acid soybean oil. Journal of Food Science, 70 (6): 395-400.

Yılmaz, H.A., 1999. Kahramanmaraş ekolojisinde farklı ekim sıklıklarının, iki soya (Glycine max (L.) Merill) çeşitinde, verim ve verim unsurlarına etkisi. Turkish Journal of Agriculture and Forestry, 23: 223-232.

Yoshida, H., Hirakawa, Y., Murakami, C., Mizushina, Y., Yamade, T., 2003. Variation in the content of tocopherols and distribution of fatty acids within soya bean seeds (Glycine max L.). Journal of Food Composition and Analysis, 16: 429-440. 